\title{
OPPORTUNITIES FOR TRANSFORMING INFORMAL SETTLEMENTS IN CARIBBEAN SMALL ISLAND DEVELOPING STATES
}

\author{
Michelle Mycoo
}

Faculty of Engineering, The University of the West Indies, Trinidad and Tobago

Email: michelle.mycoo@sta.uwi.edu*(Corresponding author)

\begin{abstract}
Informal settlements are quite complex because they consist of economically disadvantaged, often landless households located on steep hillsides, floodplains and swamps, which contribute to their exclusion from accessing infrastructure. These challenges need not be constraints; rather they offer opportunities for transformation. Such communities are generally characterised by inadequate access to safe water; inadequate access to sanitation and other infrastructure; poor structural quality of housing; overcrowding and insecure residential status. This paper uses primary and secondary data to determine the drivers which impact on the burgeoning of informal settlements in the Caribbean and analyses their implications for achieving the United Nations Sustainable Development Goal 11 which focuses on achieving safer, sustainable and resilient human settlements. The main findings of the paper are that housing shortages, delays in obtaining planning approvals, inflated land values and poverty contribute to the growth of informal settlements. However, such settlements occupy vulnerable sites where infrastructure is sometimes lacking and they help trigger environmental hazards which may be further exacerbated by climate change. Based on the key findings of the empirical evidence, the paper raises what is the critical role of engineering and engineering education in improving access by informal settlements to basic services that are fundamental in achieving sustainable, resilient human settlements and human well-being? These questions are answered within the Caribbean Small Island Developing States context and draws from a crosssection of case studies within the region.
\end{abstract}

Keywords: Informal settlements; sustainable development; resiliency; engineering education

https://doi.org/10.47412/BHCK8814

\section{Introduction}

Informal settlements are quite complex because they consist of economically disadvantaged, often landless households located on topographically challenging and environmentally sensitive lands, which contribute to their exclusion from accessing infrastructure. These challenges need not be constraints; rather they offer opportunities for transformation. In the $21^{\text {st }}$ century and beyond, a 
critical question is what is the role of engineering in improving access by informal settlements to basic services that are fundamental in achieving sustainable, resilient human settlements and human well-being?

It is essential that policymakers, decision-makers, educators and civil society recognise the transformational role of engineers in embracing the United Nations Sustainable Development Goals (UN SDGs), including social equality, gender equality, inclusiveness and well-being in informal settlements. This chapter focuses on engineering infrastructural deficiencies in informal settlements and the opportunities for closing the gap through the education of engineers. It specifically draws from the experience of Small Island Developing States (SIDS) in the Englishspeaking Caribbean and relies on primary and secondary data to identify the main drivers of unequal access to basic services in informal communities and to discuss the fundamental role of engineering in meeting these challenges and achieving the UN SDG 11.

\section{Drivers of Unequal access to Products and Services in Informal Settlements}

Unequal access to housing, land and basic infrastructure has a profound effect on the sustainability and well-being of informal settlements in English-speaking Caribbean countries. This section, drawing on primary data collected by the author and secondary data from development agencies, provides the context within which multiple drivers impact on inequalities in accessing these products and services.

In the English-speaking Caribbean, the formal housing sector cannot meet housing demand and fewer affordable houses are being built for low-income households [1]. However, the 2011 census for six English-speaking Caribbean SIDS revealed high home ownership, which may reflect a very active informal sector is providing a large percentage of housing [2]. According to data collected in 2019 from the Town and Country Planning Division (TCPD) of Trinidad and Tobago only 43\% of the total applications received were processed within the two-month statutory period. The majority of these applications were for the construction of single family dwelling units. TCPD's status reports indicate that approximately 8000 applications were received in 2017 of which only an average of $45 \%$ of development applications were approved within the statutory time period of two months according to the Trinidad and Tobago, Public Administration and Appropriations Committee, 2019. Interviews with professional planners revealed several reasons that applications were not determined within the legal timeframe for processing (See Table 1). Studies in Caribbean SIDS revealed that delays in the planning approval process that exceeds the statutory eight-week period for town planning agencies to determine planning applications also contribute to illegal housing construction [3].

Table 1: Deficiencies of development control process in Trinidad and Tobago based on interviews with Public and Private Sector Town Planners

\section{Development Control Deficiencies}

- Inordinate delays in processing development applications. Processing time for large projects exceeds 8 -week statutory period. 


\begin{tabular}{|ll|}
\hline - & $\begin{array}{l}\text { Rigid application of zoning and building standards resulted in unauthorized } \\
\text { development. }\end{array}$ \\
\hline • & Excessive appeal by public against planning decisions. \\
\hline • & $\begin{array}{l}\text { High percentage of decisions being made by Advisory Town Planning Panel as } \\
\text { opposed to Planning Agency on behalf of Minister. }\end{array}$ \\
\hline - & Limited professional planning staff to enforce against unauthorised development. \\
\hline - & Weak public participation in 1970s, 1980s and 1990s. \\
\hline
\end{tabular}

Source: Mycoo (2016)

Inflated land values and the high engineering costs of serviced land have made it impossible for economically disadvantaged households to own land. Many poor households have therefore resorted to the illegal occupation of mainly state land and some have encroached on private lands. In 2007, approximately 600,000 persons or $20 \%$ of Jamaica's population lived in squatter settlements [4]. In Trinidad and Tobago, an estimated 396 squatter settlements exist, with as much as 85,000 households or $20 \%$ of the population occupying lands illegally [1]. This situation is likely to worsen with rapid urbanization rates projected for the Caribbean [5].

Informal settlements in the English-speaking Caribbean tend to burgeon on hazard prone lands [6] and [7]. An increasing amount of evidence confirms that unauthorised occupation of sensitive terrain undermines the role of ecosystems in providing services such as watershed management, erosion control and flood mitigation [8]. Furthermore, the cost of building engineered infrastructure in these locations is high.

Sub-standard housing and the lack of infrastructure to support the well-being of inhabitants are characteristic of settlements in the Caribbean. State provision of lifeline infrastructure is often lacking in these settlements because of their illegal status. In Guyana, Jamaica and Trinidad, thousands of squatters are living without lifeline infrastructure such as water, electricity, roads and sewerage facilities [1]. Furthermore, housing in informal settlements do not adhere to a building code [1] and [7] (See Fig. 1).

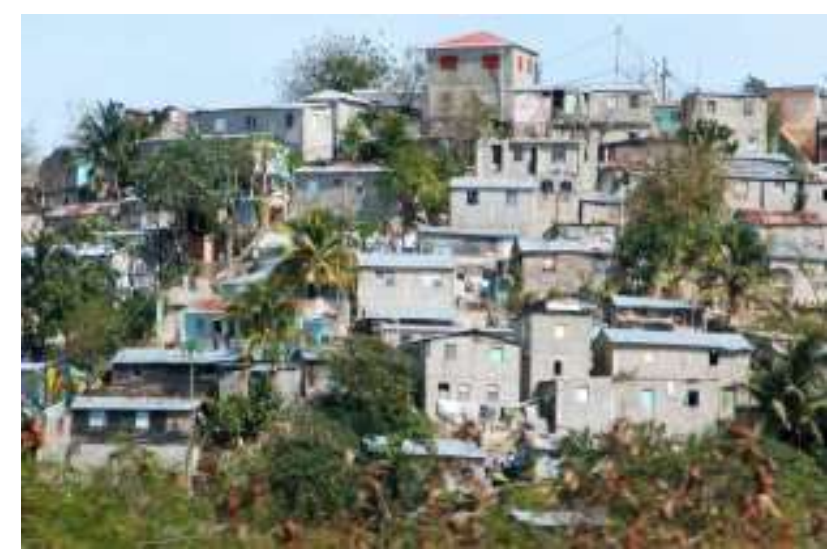

Figure 1: Informal Hillside Community in Jamaica

In the English-speaking Caribbean, informal settlements have no formal planning approval and therefore do not benefit from site development standards, building codes and engineering 
standards, which serve to protect public health and safety. Additionally, settlements lacking these standards do not have the advantage of guidelines provided by environmental impact assessments to mitigate damage and losses. As a consequence they suffer greater environmental risks in contrast to approved settlements. These risks include flooding and landslides and many households living in informal settlements experience higher economic loss resulting from damage to household assets. The lack of professional input from planners, architects, engineers, and environmentalists undermines the attainment of sustainable, resilient settlements in Caribbean SIDS.

\subsection{Informal Settlements in an Era of Climate Change}

Residents in informal settlements are most at risk to climate change because they have less coping capacity to reduce risks. In the English-speaking Caribbean, many live in most at risk hazard prone coastal areas and hillsides. Low-income urban dwellers have settled in flood prone settlements such as Sophia in Georgetown (Guyana) and Sea Lots (Trinidad) [9] and [10]. More than half the squatter settlements in Kingston, St. Andrew, and St. Thomas, Jamaica, are within 100 metres of a waterway susceptible to flooding [1]. Sea level rise also has implications for coastal marginal settlements [11].

Informal settlements in Caribbean SIDS are also at high risk because of more frequent and intense hurricanes and storm surges [12]. Category five hurricanes such as Maria and Irma in 2017 caused catastrophic damage throughout the Caribbean. Informal settlements suffered severe damage and loss arising partly because of non-compliance with building codes and planning regulations. This is not unusual because driven by poverty, squatters often use poor construction practices and breach building codes [13]. Additionally, the health of residents living in informal settlements is under threat from warmer temperatures, increased humidity and extreme weather events [14]. Dengue, Zika and Chinkingunya thrive in areas lacking in drainage infrastructure, solid waste management and vector control services [15].

\section{Holistic Education of Engineers to Assist Informal Settlements}

Vulnerabilities in informal settlements need not be disadvantages; rather they often present opportunities for innovation. In the $21^{\text {st }}$ century, the engineering fraternity is called into action to ensure that human progress is sustainable and that no single person is left behind. Engineers must ensure that the development of informal settlements is consistent with the United Nations Sustainable Development Goals (2015-2030), the Paris Climate Agreement (COP21), the Sendai Framework for Disaster Risk Reduction (2015-2030) and the United Nations Habitat III agreements (2016-2036) on rights to the city and a new urban agenda.

The following sub-sections focus on the knowledge and skills that should equip engineers to meet the critical needs of informal settlements. These insights are based on data analysed from interviews and surveys conducted by the author in addition to secondary data extracted from technical reports prepared by development agencies and scholarly literature. 


\subsection{Education to Promote Affordable Construction Techniques}

Engineers should be trained to design affordable housing which will reduce the housing deficit affecting marginalized households. They should be trained in the use of new materials and less labour intensive techniques in housing construction to minimize cost overruns often caused by high labour costs in some Caribbean SIDS. Engineers should be aware of innovative housing construction technologies that make housing affordable for disadvantaged households living in informal settlements.

\subsection{Re-designing Building Codes}

Engineer should be educated to design and implement realistic building codes, which informal settlements are more likely to adopt in housing construction. Furthermore, engineers should be trained in retrofitting housing and critical infrastructure to promote human safety and resiliency to natural hazards. Building codes adopted in developing countries have been often criticised because they contribute to high housing costs for low-income households. It is argued that this results in low or no compliance in the use of building codes by economically disadvantaged households. Part of the engineer's training should be the development of communication and negotiating skills to drive the process of incremental adoption of realistic building codes. Prevatt et al. (2012) recommends a multidisciplinary path forward that incorporates engineering research and social and economic studies into a new design paradigm leading to building code changes and social practices that will improve resistance and mitigate future losses at a community level [16].

\subsection{Educating Engineers for Climate Change Adaptation and Disaster Risk Reduction}

Engineers in the $21^{\text {st }}$ century must be educated to find innovative ways to promote climate change adaptation and disaster risk reduction in marginalized communities. It is necessary to train engineers in designing innovative, affordable climate resilient building codes to be used in the construction of safer housing, resilient infrastructure and climate proof shelters in informal settlements. Part of their training should emphasize the adoption of an incremental approach to housing construction that enables low-income households to utilise building codes as additional funding becomes available. Many disadvantaged Caribbean households depend on remittances from overseas family members, access funds from indigenous pooled savings such as the Sou (Trinidad) or Partner (Jamaica) or credit unions. In lowering their exposure to risks, alternative sources of informal financing can be tapped to encourage compliance with safety regulations by poor households.

Given the severity of flooding, drainage engineers should be educated to use indigenous building practices in minimizing losses. For example, engineers should be knowledgeable on the use of stilts or elevated floors as used in Georgetown (Guyana) and Chaguanas (Trinidad) [9]. Such building and architectural techniques are less costly when compared with the construction of drainage canals, re-engineered river courses, dykes [10] and [17] and maladaptation techniques used by households [9]. Additionally, watershed degradation by illegal hillside settlements impacts on coral reefs that are important to the blue economy and tourism. A new generation of engineering professionals need to be trained in hydrology, coral reef monitoring and coastal conservation [10]. Moreover, engineers should be trained to collaborate with other professionals such as architects and town and country planners who influence building practices. 


\subsection{Environmental Engineering and Green Infrastructure}

Environmental and civil engineers require training in the use of green infrastructure to minimize the impact of poor land settlement practices and natural hazards on informal communities. The engineering curriculum should emphasize the importance of ecosystems and the need to protect fragile SIDS ecosystems from maladaptation practices in land development and infrastructure provision. Ecosystems are nature's way of providing green infrastructure that lowers infrastructural service provision costs, reduces the vulnerability of these communities, enhances their adaptation to climate change, and builds resiliency to disaster risks.

Engineering education in an era of climate change and scare financial resources should underscore the importance of multi-functional, soft engineering alternatives to grey infrastructure in low income, informal settlements. Engineers should also be trained to work in partnership with informal communities, town and country planners and environmentalists to develop and maintain green zones within these settlements. Moreover, engineers can play a major role in the creation of green jobs.

\subsection{Engineering Education and Water Provision in Informal Settlements}

Limited access to potable water in informal settlements calls for refocusing engineering education to find effective solutions to improve water access. Firstly, women in informal settlements spend much time collecting water for domestic use [18] [19]. Secondly, the state provides subsidised standpipe water or truck borne water because conventional piped water supply is costly to provide in informal settlements located on hilly terrain and service interruptions are common. Thirdly, there are increasing droughts and the closure of reservoirs in the aftermath of hurricanes and storms because of climate change in Caribbean SIDS [20]. These drivers should influence the education of engineers to design solutions aimed at addressing inequality, unreliability and water security. Some counties have a long history of self-financing domestic rainwater harvesting (DRWH). DRWH encourages incremental improvement of household and community water supply by facilitating user investment over time [21]. Engineering education should promote DRWH projects, which are easily replicable with the use of affordable technologies [21]. DRWH systems are also easy to maintain by informal communities in comparison to conventional piped water supply systems.

Engineers should also be educated on the importance of integrated water resources management (IWRM) in solving water problems experienced by informal settlements. IWRM is holistic in its approach to water service provision through its promotion of the principles of water as an economic good, equity, gender sensitivity, and stakeholder participation. Engineering institutions should ensure that qualified engineers know and understand the appropriate technologies, legislative frameworks and latest best practice for adopting a systems based approach to water resources management and in achieving water security.

\subsection{Engineering Education, Solid Waste Management and Sewage Disposal}

Engineers should be educated to search for practical solutions to the inadequate solid waste management services and sewerage disposal systems because they impact on the health and safety of marginalized households. As part of this training, engineers should become familiar with unconventional techniques for waste minimization, recycling and reuse of products and compost production. Such knowledge would enhance their capacity to conduct education awareness 
workshops for households living in informal settlements especially those located in hilly terrain that are inaccessible to waste disposal trucks.

\subsection{Engineering Education and Energy Efficiency}

Engineers should be trained to design and implement new, low cost, environmentally friendly technologies such as alternative energy. Informal settlements cannot afford electricity supplied by utility providers. Solar energy is an alternative to the use of fossil fuels such as firewood and charcoal. Wind energy is also a renewable energy source. Caribbean engineers should be trained to design affordable solar panels and wind turbines (See Fig. 2). These new technologies present opportunities for informal communities to gain access to cleaner, affordable, sustainable energy.

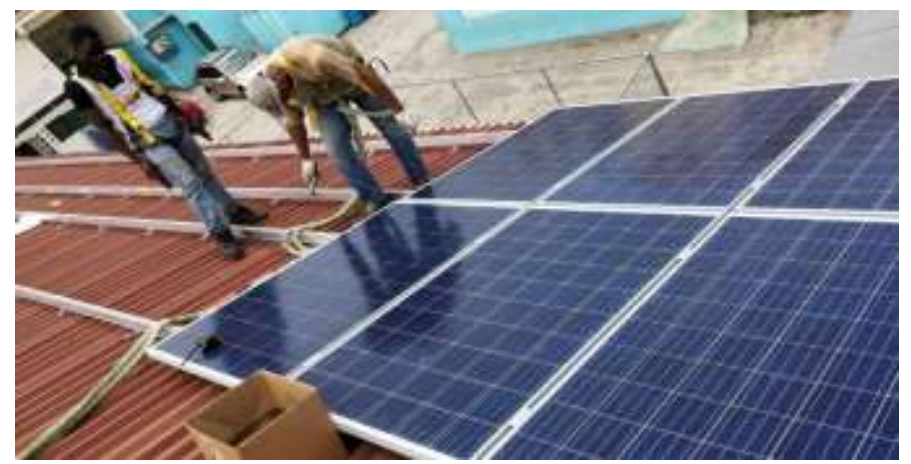

Figure 2: Solar panels being installed on the roof in St Andrew Settlement, Jamaica (UNDP, 2017)

\subsection{Engineering Education and Improved Mobility}

Engineers should be educated to improve the mobility of persons living in marginalized communities. Impoverished households are severely affected by limited mobility stemming from inadequate road and street networks and the lack of public transport to peripheral settlements. They cannot commute easily to employment centres, health and educational facilities and spend much time and money in commuting. Women, children and the elderly are particularly affected by the lack of transportation facilities. The training of engineers should highlight the importance of improving vehicular and pedestrian access coupled with an integrated multi-modal, sustainable transportation system to service these settlements. A sustainable transportation system should be designed by transportation engineers to reduce poverty, improve safety and enhance human wellbeing in informal settlements.

\subsection{New Technologies in Engineering Education}

Engineering practice is often undermined by the scarcity of data on informal settlements. The new data revolution enables data capture using satellite imagery, drones and geographic information tools to track the occupancy of unserviced lots and design better interventions. Mobile technology also facilitates community involvement in data acquisition. Engineers should be educated on the available new technologies for data capture, analysis, interpretation and communication. These technologies will allow engineers to become more innovative in designing robust solutions that resolve the challenges faced by marginalized communities. 


\section{Conclusion}

Engineers should be educated to engage with multiple partners in finding pioneering solutions to the complex issues and challenges faced by informal settlements. An interdisciplinary approach to problem solving should form an essential part of the curriculum used in educating engineers. With the collective expertise of engineers, planners, architects, land surveyors, environmentalists, economists and community input (citizen science), human progress is possible. Ultimately, engineers must be educated to be visionary, inventive, entrepreneurial and technologically savvy in crafting home grown solutions to the problems that are relevant to their society inclusive of informal settlements.

\section{Recommendations}

This paper provides key recommendations, which may help build capacity and enhance knowledge transfer among engineers to effectively address challenges faced by informal settlements in Caribbean SIDS. The key points are by no means an exhaustive list. They are as follows:

- Educators of engineers, policymakers and implementing agencies need to prioritise the development of innovative engineering solutions aimed at improving access to housing and infrastructure by informal settlements.

- Housing, town planning, infrastructural and environmental agencies can enhance opportunities for multi-disciplinary collaboration among engineers, architects, town planners and environmentalists to close the gap in meeting housing, land and infrastructural services in these communities.

- The use by housing, town planning and infrastructural agencies of a participatory, bottomup approach rather than a top-down, technical approach to problem solving is essential in tackling housing and infrastructural deficiencies.

- Educators can design courses to help engineers learn to be "technology and knowledge" brokers to improve their understanding and interpretation of the needs of informal communities and connect them to solutions.

- Engineers can learn to value the solutions that arise from communities and use the actual capacities of the same communities to develop and implement innovative solutions.

- Engineers working within communities can play a key role in stimulating and strengthening the creativity and capacities of such communities to find and implement solutions.

- Engineering entrepreneurship is useful in designing and implementing innovative, low cost technologies to serve these communities. Design competitions and trade fairs are well suited to encouraging engineering entrepreneurship. 
- Climate change demands a leadership role of engineers in climate proofing these communities. Training courses in climate change adaptation conducted by universities, technical institutes and professional organisation should become a priority.

- Excellent verbal, written and graphic communication skills are needed by engineers to build knowledge awareness and stimulate behavioural change in informal settlements where there is limited compliance with building codes and infrastructural standards which exacerbates climate change impacts.

- Behavioural change in informal settlements is best complemented by training engineers to value, better use and re-use good practices and techniques, as well as traditional knowledge when they exist in such communities.

- National governments, development partners and professional engineering associations should encourage engineers to offer their skills pro bono in conducting post-disaster damage assessment and projects that improve human living conditions.

- Government agencies can help expose engineers to the use of the Green Climate Fund in remedying infrastructural deficits that impact on the vulnerability of informal settlements informal.

- Information communication technology enhances the engineer's capacity to capture, analyse and interpret data thereby sharpening his or her practical and creative problem solving skills in meeting the needs of informal settlements informal.

- Forming strategic alliances with governments, development partners and the private sector can strengthen the implementation capacity of engineers.

- Development agencies can help expose engineers to the importance of adopting the public private partnership model which draws on the combined talents of the public and private sectors in effectively delivering infrastructural services in these communities.

- Development partners, governments and the private sector can encourage engineers to undertake research and innovation in housing and infrastructure provision by providing incentives such as partial financial support.

- Engineering educators together with diplomacy and conflict resolution specialists can teach engineers skills to resolve conflicts in service provision in informal settlements.

- Professional engineering associations are well suited to conducting continuing professional development courses and workshops as part of the lifelong learning of engineers to better understand and close the gap in the science, policy and practice. 


\section{References}

[1] R. Rajack and M. Frojmovic. Forthcoming. Housing and Land Markets in Trinidad and Tobago: Inputs to the IDB's Country Challenges Document for Trinidad and Tobago. Washington, DC: Inter-American Development Bank.

[2] P. McHardy and M. Donovan. 2016. The State of Housing in Six Caribbean Countries. Inter-American Development Bank, Washington D.C. https://publications.iadb.org/handle/11319/7514

[3] M. A. Mycoo. Reforming Spatial Planning in Anglophone Caribbean Countries. Planning Theory and Practice Vol. 18, No. 1, (2016) 89-108.

[4] Government of Jamaica. 2007. Rapid Assessment of Squatting Report 2007. Kingston, Jamaica: Ministry of Water and Housing.

[5] M. A. Mycoo. A New Urban Agenda for the Caribbean Post Habitat III. Habitat International Vol. 69, (2017) 68-77.

[6] M. Mycoo, C. Griffith-Charles and S. Lalloo. Land management and environmental change in smallisland-developing states: the case of St. Lucia. Regional Environmental Change Vol. 17, No.4, (2016) 112 .

[7] B. Carby. Integrating disaster risk reduction in national development planning: experience and challenges of Jamaica, Environmental Hazards Vol. 17, No. 3, (2017) 219-233.

[8] United Nations Environment Programme. 2015. Global Synthesis Report of the Project for Ecosystem Services, UNEP, Ecosystem Services Economics Unit, Division of Environmental Policy Implementation. https://reliefweb.int/sites/reliefweb.int/files/resources/Global synthesis report.pdf

[9] M. Mycoo. Autonomous household responses and urban governance capacity building for climate change adaptation. Georgetown, Guyana. Urban Climate Vol. 9, (2014) 134-154.

[10] M. Mycoo and M. G. Donovan. 2017. A Blue Urban Agenda: Adapting to climate change in the coastal cities of Caribbean and Pacific Small Island Developing States. Washington: IDB.

https://publications.iadb.org/handle/11319/8264.

[11] M. Simpson, C. Clarke, D. Scott and A. Clarke. 2012. Coastal Setbacks in Latin America and the Caribbean. Inter-American Development Bank.

https://publications.iadb.org/bitstream/handle/11319/5567/Coastal\%20Setbacks\%20in\%20Latin\%20Ame rica\%20and\%20the\%20Caribbean.pdf?sequence=1. Accessed 20 April 2017

[12] L.A. Nurse, R.F. McLean, J. Agard, L.P. Briguglio, V. Duvat-Magnan, N. Pelesikoti, E. Tompkins, and A.Webb. 2014. Small islands. In: Climate Change 2014: Impacts, Adaptation, and Vulnerability. Part B: Regional Aspects. Contribution of Working Group II to the Fifth Assessment Report of the Intergovernmental Panel on Climate Change [Barros, V.R., C.B. Field, D.J. Dokken, M.D. Mastrandrea, K.J. Mach, T.E. Bilir, M. Chatterjee, K.L. Ebi, Y.O. Estrada, R.C. Genova, B. Girma, E.S. Kissel, A.N. Levy, S. MacCracken, P.R. Mastrandrea, and L.L.White (eds.)]. Cambridge University Press, Cambridge, United Kingdom and New York, NY, USA, pp. 1613-1654. 
[13] D. Prevatt, J. van de Lindt, E. W. Back, A. Graettinger, S. Pei, W. Coulbourne, R. Gupta, D. James, and D. Agdas. Making the case for improved structural design: Tornado outbreaks of 2011. Leadership and Management in Engineering Vol. 12, No. 4, (2012) 254-270.

[14] M.A. Mycoo. Beyond 1.5C: vulnerabilities and adaptation strategies for Caribbean Small Island Developing States. Regional Environmental Change, (2017) 1-13.

[15] K.L. Ebi, N.D. Lewis and C. Corvalan. Climate variability and change and their potential health effects in small island states: information for adaptation planning in the health sector. Environmental Health Perspective Vol. 114, No.12, (2006) 1957-1963.

[16] D.O. Prevatt, L.A. Dupigny-Giroux and F. Masters. Engineering perspectives on reducing hurricane damage to housing in CARICOM Caribbean islands. Natural Hazards Review Vol. 11, (2010) 140-150.

[17] United Nations Habitat. 2011. Global Report on Human Settlements 2011: Cities and Climate Change. London, Earthscan.

[18] M. Mycoo. Water provision improvements: A case study of Trinidad. Willingness to pay, pricing policy, cost reduction and institutional strengthening. Ph.D. Thesis, McGill University, Canada, 1996.

[19] J. L. Schneiderman and R. Reddock. Water, women and community in Trinidad, West Indies Natural Resources Forum Vol. 28, No. 3, (2004) 179-188.

[20] M. A. Mycoo. Achieving SDG 6 water resources sustainability in Caribbean Small-Island Developing States through Improved Water Governance. Natural Resources Forum Vol. 42, No. 1, (2017) 54-68.

[21] E. J. Peters. Financing domestic rainwater harvesting in the Caribbean. Journal of Sustainable Development Vol. 10, No. 5, (2017) 107-115. 